\title{
Deixis used in the novel entitled the good muslim by tahmima anam
}

\author{
Siska Purwanti ${ }^{1}$, Rusman Roni ${ }^{2}$, Artanti Puspita Sari ${ }^{2}$ \\ ${ }^{1}$ Sekolah Menengah Pertama Negeri 2 Tanah Abang, Indonesia \\ ${ }^{2}$ Universitas PGRI Palembang, Indonesia
}

\begin{tabular}{l}
\hline Article Info \\
\hline Article history: \\
Received Jul $11^{\text {th }}, 2021$ \\
Revised Aug $18^{\text {th }}, 2021$ \\
Accepted Aug $30^{\text {th }}, 2021$ \\
\hline
\end{tabular}

\section{Keyword:}

Novel

The good muslim

Deixis.

\begin{abstract}
This research investigated Deixis used in the novel entitled The Good Muslim by Tahmima Anam.This study was conducted to find out; (1) types of deixis contained in utterances of the novel entitled the Good Muslim by Tahmima Anam, (2) types of deixis were used most in the Novel entitled The Good Muslim by Tahmima Anam. Therefore, it gived significant to the author herself, the learners, other researchers and english teachers. The writer used levinson's theory in analyzing the data. The methodology of this research was qualitative descriptive study. The technique used to collect the data was documentation. The data was taken from 1.972 utterances of the novel entitled the Good Muslim by Tahmima Anam. From the data have been analyzed, it was found that there were five types of deixis, they were person deixis occured 1.723 times $(87.4 \%)$, place deixis occured 53 times $(2.7 \%)$, time deixis occured 68 times (3.4\%), discourse deixis occured 83 times (4.2\%), person deixis occured 45 times $(2.3 \%)$. The most commonly used types of deixis was person deixis occuring 1.723 times $(87.4 \%)$.
\end{abstract}

(C) 2021 The Authors. Published by IICET.

This is an open access article under the CC BY-NC-SA license (https://creativecommons.org/licenses/by-nc-sa/4.0

\section{Corresponding Author:}

Purwanti, S.,

Sekolah Menengah Pertama Negeri 2 Tanah Abang, Indonesia

Email: siska.rudini89@gmail.com

\section{Introduction}

Yule [1] stated that Pragmatics are the analysis of the link between the linguistic forms and the users of these forms. The advantages of pragmatic language learning are that a person speaks about the intended purpose of the people, their assumptions, motivations and priorities and the kinds of behavior they have when talking. Pragmatics focuses on the significances of dialog in which the speaker suggests. Simply put, pragmatics are studied language which is not spoken specifically. Rather the speaker implies or indicates a meaning, and the listener assumes the right aim. The most obvious way to relate language is through the phenomenon of Deixis.

Yule [1] has claimed that deixis is one of the fundamental things we talk about in the Greek technical term. Deixis is a denoting with words. The word deixis is the language used to complete the grading. Levinson [2] explained that deixis refers to the phenomenon of understanding, which means the importance of contextual knowledge. Deixis are words or sentences that require contextual information to express significance.

Information on the speaker, the addressee, the time and the place consists of the contextual information of the utterance described by Levinson [2]. For example if we take a close look at tomorrow's sentence, who am I, who am I, who am I, and who am I going to mention tomorrow? If we do not know the time, place and who 
the speaker is, i.e. the context of the word, the importance of this word cannot be established. Expressions such as I, you, we, this, that this, this, all of this, tomorrow are all indexed and the listener must know the speaker and the time and place for the utterance in order to fully understand what is being said and said. Certain phrases are not understood unless people are aware of the utterance meaning, their participants' status, the speaker's purpose, their position and time. These sentences do not mean constantly, and they are referred to as deixis words $[3,4,5]$.

Phrases of Deixis are central to pragmatics since they contribute to the sense of language. In our everyday lives, for example in conversations, in journals and literature, we also experience the use of deixis in various ways. One of these can be seen in fictional works, namely novels. The novel comes from the Italian "novella" meaning "a story or a piece of news." Dialog is formed between characters of the book; some words contain deixis elements that are analyzable. In this analysis the novel by Anam [3], titled "The Good Muslim," is the novel to be discussed. This novel is addressed by the author, as it is a moral lesson of the deixis that is inserted in the plot. after reading the novel, the author wanted to know the words of the good Muslier. As the author attempted to discover, it was understood that the terms contain deixis expressions.

\section{Method}

This research was conducted at SMA Negeri 10 OKU. The research period was carried out for 3 (three) months, starting from September 2020 to November 2020. Research Methods Zuldafrial [6] argues that the data source is the subject from which data can be obtained. Furthermore, Sugiyono [7] explains that when viewed from the data source, data collection can use primary and secondary sources. Primary data sources are data sources that directly provide data to data collectors, and secondary sources are sources that do not directly provide data to data collectors. Based on the theoretical explanation above, the primary data sources obtained from this study were 37 teachers in SMA Negeri 10 OKU consisting of 13 PNS teachers and 24 honorary teachers. While the secondary data source is in the form of interviews aimed at school principals and teachers related to the professionalism of teachers in teaching.

Arikunto [8] states that in a study data is needed. In data collection, techniques are needed, both techniques in providing data, and techniques in classifying the data that has been collected. The data collection method is a method used to collect data, while the data collection technique is the method used in carrying out the method that has been chosen. In short, it can be said that a method is a method, whereas a technique is a way to carry out a method that has been chosen. This research is a field study, so the desired data can only be obtained from the field, the research location. Data collection techniques in this study include the following [9, 10, 11]:

According to Arikunto [8], interviews or interviews are data in which research is face to face with respondents in order to obtain the required data or information. The interview method is a method that is very effective in qualitative research. The interview used in this research is a structured interview, which is to ask written questions first as a guide but the element of freedom is still maintained, so that reasonableness can still be maximally achieved to obtain in-depth data. According to Arikunto [8], observation is defined as systematic observation and recording of the symptoms that appear on the research object. Observations and records are made of the symptoms that appear on the object where the event occurs or the process in each school.

Documentation is a data event is taking place, so that the observer is with the object being investigated, which is called observational observation that the researcher will carry out is direct observation of the occurrence of events, namely how the school-based management process and teacher professionalism and teacher performance in the learning collection technique in order to obtain written facts, namely in the form of documents, reports, archives and / or other written materials related to the focus of research [8]. The documentation used as data collection material in this study is in the form of interview guidelines and interview results sheets, research permits, school profiles which include learning resources and other supporting documents in order to complement the research data.

The data analysis techniques in this study were analyzed qualitatively and quantitatively. [7] states that qualitative data analysis is a continuous, repetitive and continuous effort. According to [7], there are three stages of qualitative data analysis, namely: data reduction, display or presentation of data as well as drawing conclusions and data verification. Meanwhile, quantitative data analysis uses a formula to input the scores from the research results [8]. 


\section{Results and Discussions}

SMA Negeri 10 OKU which was used as the research location is located on Jalan Raya Baturaja-Muaradua, Tanjung Lengkayap Village, Lengkiti District, Ogan Komering Ulu Regency. In the learning process at SMA Negeri 10 OKU held at 07.30 WIB to 14.15 WIB, while extracurricular activities were carried out on Saturdays which were held at 14.00 WIB until 15.30 WIB.

Based on the research observation findings data, the following data were obtained:

1) Principal's Office $\square$ Good

2) Teacher's Room $\square$ Good

3) Study Room $\square$ Good

4) Student desks $\square$ Good

5) Student seats $\square$ Good

6) UKS Room $\square$ Good

7) Library Room $\square$ Good

8) Chemical Laboratory $\square$ Good

9) Biology Laboratory $\square$ Good

10) Physics Laboratory $\square$ Enough

11) Computer Laboratory $\square$ Good

12) Mushollah Room $\square$ Good

13) School Canteen $\square$ Good

14) Sports Equipment $\square$ Something was broken

15) Art Tools $\square$ Something's broken

16) School Field $\square$ Good

Teacher Observation Results:

1) The teacher plans the lesson plan

2) The teacher makes lesson plans

3) Teachers in implementing learning.

4) Teachers in evaluating learning outcomes

5) Teachers in providing guidance to students

6) Teachers in improving the quality of education

At SMA Negeri 10 OKU in learning activities assisted by 34 teachers consisting of 13 civil servant teachers and 21 honorary teachers, with a total of 401 students and 12 study groups consisting of 4 (four) study groups class X (ten), 4 (four) class XI (eleven) study groups, and 4 (four) class XII (twelve) study groups.

Regarding the professionalism of teachers in teaching, the best graduation rate in SMA Negeri 10 OKU in 2017/2018 the highest score was 5.60 in 2018/2019 the highest student passing score was 5.55 and while for the 2019 learning year / 2020 UNBK, whose name changed to USP (Education Unit Examination) could not be implemented due to the COVID-19 outbreak, an epidemic that has hit the whole world in general and in particular Indonesia which did not allow the implementation of the USP.

\section{Conclusions}

Based on the research findings, it is known that the principal has played a role in the supervision carried out as an effort to improve teacher professionalism in teaching. The supervisory role of the principal is evidenced by the teacher in planning the lesson plans which are made reported and approved by the principal and according to the curriculum. The teacher was carrying out the learning process according to the learning device guidelines and using props. Teachers in delivering learning have used other sources from books with various publishers besides handbooks. In the learning process the teacher has done learning activities outside the classroom, this is done so that the learning process is not boring. When the teacher delivers the learning material using teaching aids, the students better understand the material presented. Because the teaching aids used can be motivate students to learn. The teacher provides guidance to students who have difficulty learning. The teacher gives directions to students to always carry handbooks when participating in the learning process. Teachers often provide guidance and counselling when there are students who commit disturbances by giving advice and directing these students not to repeat their actions [12]. 
Based on the description above, the researcher provides input in the form of suggestions to the following parties.

1. The principal, in providing supervision, should be carried out on a schedule so that evaluation can be carried out and existing deficiencies can be overcome, so that the quality of education can be even better.

2. Teachers should always improve professionalism in teaching, either by adding insight, improving teaching techniques so that students are able to absorb any material presented.

3. The Education Office should always provide direction and guidance for schools in Ogan Komering Ulu Regency, especially in SMA Negeri 10 OKU so that the quality of education can be improved.

\section{References}

Yule, G. (1996). Pragmatics. Oxford: Oxford University Press.

Levinson, S. (1983). Pragmatics. London: Cambridge University Press.

Anam, T. (2011). The Good Muslim. London: Canogate.

Semino, E. (2011). Deixis and fictional minds. Style, 45(3), 418-440.

Fraenkel, J.R, et al. (2012). How to Design and Evaluate Research in Education 8th Edition. New York: The McGraw-Hill Companies.

Wibowo, A. I. (2018). Deixis and its context used in "Girl In Pieces" novel by Kathleen Glasglow.

Hennink, M., Hutter, I., \& Bailey, A. (2020). Qualitative research methods. Sage.

Merriam, S. B. (2002). Introduction to qualitative research. Qualitative research in practice: Examples for discussion and analysis, 1(1), 1-17.

Van de Vijver, F., \& Leung, K. (1997). Methods and data analysis of comparative research. Allyn \& Bacon.

Ott, R. L., \& Longnecker, M. T. (2015). An introduction to statistical methods and data analysis. Nelson Education.

Myers, J. L., Well, A., \& Lorch, R. F. (2010). Research design and statistical analysis. Routledge.

Mandel, J. (2012). The statistical analysis of experimental data. Courier Corporation 